\title{
Speciated PM Composition and Gas and Particle Emission Factors for Diesel Construction Machinery in China
}

\author{
Qingyao Hu ${ }^{1}$, Cheng Huang ${ }^{1 *}$, Liping Qiao ${ }^{1}$, Yingge Ma ${ }^{1}$, Qiang Yang ${ }^{2}$, Wei Tang ${ }^{2}$, Min Zhou ${ }^{1}$, \\ Shuhui Zhu', Shengrong Lou ${ }^{1}$, Shikang Tao', Yun Chen ${ }^{3}, \mathrm{Li} \mathrm{Li}^{1 *}$ \\ ${ }^{1}$ State Environmental Protection Key Laboratory of Cause and Prevention of Urban Air Pollution Complex, Shanghai \\ Academy of Environmental Sciences, Shanghai 200233, China \\ ${ }^{2}$ Hangzhou Institute of Environment Sciences, Hangzhou 310014, China \\ ${ }^{3}$ Hangzhou Motor Vehicle Exhaust Pollution Management Office, Hangzhou 310014, China
}

\begin{abstract}
On-board emission measurements were performed on nine diesel construction machines operated under real-world conditions in China. The emission factors (EFs) for $\mathrm{NO}_{\mathrm{x}}, \mathrm{CO}$, the total hydrocarbons, $\mathrm{PM}$, and the particle number concentration were determined under actual operating conditions, i.e., during idling, moving, and working. To investigate the chemical composition of PM from diesel machinery, organic carbon (OC), containing particulate organic matter (POM); elemental carbon (EC); water-soluble ions (WSIs); and elements were also analyzed herein. OC was the most abundant component (contributing $39.3 \pm 11 \%$ of the mass), followed by EC $(37.7 \pm 13 \%)$. POM species, including $n$-alkanes, hopanes, polycyclic aromatic hydrocarbons (PAHs), and $n$-fatty acids, contributed approximately $2.4-6.4 \%$ of the total PM mass. Compounds with 3 or 4 aromatic rings, including pyrene, phenanthrene, and fluoranthene, dominated the particulate PAHs, accounting for $62 \%$ of the total mass. These results are consistent with those of previous studies and can help to minimize uncertainties in emission inventories and source apportionment for non-road machinery.
\end{abstract}

Keywords: Non-road machinery; Emission factors; PM components; PAH emissions; Diesel emissions.

\section{INTRODUCTION}

Emissions from non-road machinery have attracted increasing attention due to their increasing contributions to emission inventories over recent decades (McDonald et al., 2015; Campbell et al., 2018a, b). Nitrogen oxides $\left(\mathrm{NO}_{\mathrm{x}}\right)$ and particulate matter (PM) are among the major pollutants in diesel exhaust. $\mathrm{NO}_{\mathrm{x}}$ is a key precursor to ozone and nitrate in $\mathrm{PM}_{2.5}$ in the atmospheric boundary layer (Seinfeld and Pandis, 2006), while PM contains abundant organic carbon $(\mathrm{OC})$, elemental carbon (EC), and intermediate volatility organic compounds (iVOCs), inorganic components that greatly impact visibility (Pitchford et al., 2007; Li et al., 2017; Chow et al., 2018), human health (IARC, 2012; Mohankumara and Senthilkumar, 2017), and global warming (Ayhan, 2009; Smith et al., 2009).

The amount of non-road machinery has increased considerably over the last decade in China. The number of non-road construction machines in China reached 7.2 million

\footnotetext{
* Corresponding authors.

E-mail address: huangc@saes.sh.cn (C. Huang); lili@saes.sh.cn (L. Li)
}

by the end of 2017, a $67 \%$ increase over the year 2012 (MEP, 2018). However, Chinese emission standards for non-road diesel machinery currently lag two stages behind those for on-road diesel vehicles; in 2015, Stage 3 emission standards were implemented for non-road diesel machinery, while on-road diesel vehicles were subject to Stage 5 standards. This delay in emission standard implementation has stimulated higher emissions from non-road diesel machines in China. In urban areas, non-road machinery consists primarily of construction machinery; construction machinery in turn is dominated by excavators, loaders, and forklifts, which account for $26.8 \%, 27.3 \%$, and $41.8 \%$, respectively, of the total number of construction machines (MEP, 2018).

To evaluate emissions from non-road machinery, Wang et al. (2016) compiled a non-road machinery emission inventory for 2012 in China. However, this emission inventory contains relatively large uncertainties due to limited data on real-world emission factors (EFs) for non-road machines (Wang et al., 2016). Thus, additional measurements of non-road machinery emissions have been conducted in the past decade. Abolhasani et al. (2008) performed realworld measurements of emissions from diesel excavators using a Portable Emission Measurement System (PEMS) in 2008. Since then, this method has been applied to other 
types of construction equipment and to the evaluation of emission reductions due to fuel selection and new engine technologies (Frey et al., 2008; Frey et al., 2010; Pirjola et al., 2017; Zavala et al., 2017). Recent localized measurements of construction machinery emissions conducted in China have found that EFs are generally higher for Chinese machines than for American machines (Fu et al., 2012; Li et al., 2016). Particulate and gaseous species, including OC, EC, water-soluble ions (WSIs), and elements, have come under scrutiny (in addition to criteria pollutants, such as $\mathrm{NO}_{\mathrm{x}}$ ) for their importance in source apportionment, human health, and climate change (Lindgren et al., 2011; Cui et al., 2017). However, the characteristics of particulate and gaseous emissions, and particularly organic compound emissions, from on-road diesel construction machinery remain largely unknown.

In this study, EFs were determined for nine diesel construction machines (viz., four excavators, three wheel loaders, one bulldozer, and one roller) via on-board measurements under real-world operating conditions. Measurements were performed during typical operating modes, including idling, moving, and working. The PM chemical composition was determined via OC, EC, WSI, elemental, and particulate organic matter (POM) analysis. The results can be used to quantify real-world emissions and develop emission inventories for construction machinery in China.

\section{EXPERIMENTAL METHODS}

\section{Test Machines}

In this study, emission measurements were carried out on nine non-road machines, viz., four excavators (EX), three wheel loaders (WL), one bulldozer (BD), and one roller (RL). These test machines represent the majority of the construction machinery types in China, accounting for $26.9 \%, 27.3 \%, 1.1 \%$, and $2.1 \%$, respectively, of the total fleet (MEP, 2018). These machines featured rated power outputs between 83 and $162 \mathrm{~kW}$, which is representative of the power distribution of construction machinery in the Yangtze River Delta region in China (Lu et al., 2017), and model years between 2004 and 2016. The machine technical specifications, such as emission standards, engine displacement, and rated power, are presented in Table 1. The test machines were rent from several construction companies, and the emission measurements were performed at a large construction site in Hangzhou, China during December 2016. In this study, four excavators (EX), three wheel loaders (WL), and one roller (RL) were fueled with low-sulfur diesel (Fuel Sample 1) which were uniformly supplied by the same gas station at the same time. The bulldozer (BD) was fueled with low sulfur diesel (Fuel Sample 2), which was supplied by the fuel truck. The test fuel properties are presented in Table 2.

\section{Emission Measurement System}

An on-board emission measurement system was constructed for this study. The system consists of a portable emission measurement system (PEMS), particulate

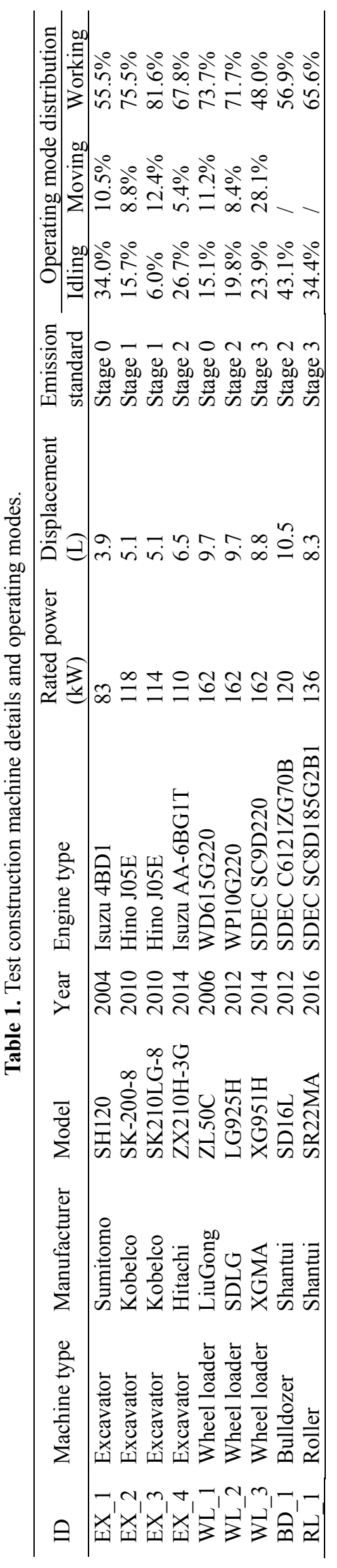


Table 2. Test fuel properties

\begin{tabular}{llll}
\hline \multirow{2}{*}{ Properties } & \multirow{2}{*}{ Unit } & \multicolumn{2}{c}{ Value } \\
\cline { 3 - 4 } & & Fuel Sample 1 & Fuel Sample 2 \\
\hline Density at $20^{\circ} \mathrm{C}$ & $\mathrm{kg} \mathrm{m}^{-3}$ & 821.9 & 827.4 \\
Kinematic viscosity at $20^{\circ} \mathrm{C}$ & $\mathrm{mm}^{2} \mathrm{~s}^{-1}$ & 4.5 & 4.7 \\
Flash point (closed) & ${ }^{\circ} \mathrm{C}$ & 92 & -24.3 \\
Cold filter point & ${ }^{\circ} \mathrm{C}$ & -27.6 & -32 \\
Freezing point & ${ }^{\circ} \mathrm{C}$ & -36 & 217.9 \\
Initial boiling point & ${ }^{\circ} \mathrm{C}$ & 221.5 & 236 \\
Temperatures for evaporation of $10 \%$ & ${ }^{\circ} \mathrm{C}$ & 226.2 & 273.7 \\
Temperatures for evaporation of $50 \%$ & ${ }^{\circ} \mathrm{C}$ & 267 & 325.3 \\
Temperatures for evaporation of $90 \%$ & ${ }^{\circ} \mathrm{C}$ & 323.1 & 52.4 \\
Cetane number & - & 52.3 & 43.9 \\
Low calorific value & $\mathrm{MJ} \mathrm{kg}{ }^{-1}$ & 43.9 & 86.1 \\
Carbon content & $\%, \mathrm{~m} \mathrm{~m}^{-1}$ & 86 & 13.7 \\
Hydrogen content & $\%, \mathrm{~m} \mathrm{~m}^{-1}$ & 13.8 & 1.5 \\
Oxygen content & $\%, \mathrm{~m} \mathrm{~m}^{-1}$ & 0.4 & 35 \\
Sulfur content & $\%, \mathrm{mg} \mathrm{kg}^{-1}$ & 8 & 1.1 \\
Total insolubles & ${\mathrm{mg} 100 \mathrm{~mL}^{-1}}$ & 0.8 & 0.1 \\
Acidity & $\mathrm{mgKOH} \mathrm{100} \mathrm{mL}$ & $<0.1$ & \\
\hline
\end{tabular}

measurement, and collection system. The PEMS system (SEMTECH-ECOSTAR; Sensors, Inc., USA), which was used to measure gaseous species, featured a non-dispersive infrared (NDIR) analyzer for $\mathrm{CO}$ and $\mathrm{CO}_{2}$ measurements, a chemiluminescence detector (CLD) for $\mathrm{NO}$ and $\mathrm{NO}_{2}$ measurements, and a flame ionization detector (FID) for total hydrocarbon (THC) measurements. The system was zeroed with pure nitrogen and calibrated with standard gases before each test. The dilution system (FPS 4000; Dekati, Finland) was connected to an Engine Exhaust Particle Sizer spectrometer (EEPS 3090; TSI Inc., USA) and a four-channel PM sampling system; the EEPS 3090 was used to simultaneously measure the instantaneous PM and particle number (PN) concentrations from 5.6 to $560 \mathrm{~nm}$ with 32 particle-size channels. During the measurements, the tailpipe exhaust was vented into a mass flow measurement device (SEMTECH EFM; Sensors, Inc., USA) to measure the exhaust flow rate using pitot tube technology. Two exhaust samples were extracted from the mass flow measurement device. One was sent into the PEMS system, and the other was sent into the dilution system. Both sampling lines were heated to $190^{\circ} \mathrm{C}$ before entering the instruments. The dilution was performed using HEPA-filtered compressed air in two stages. The primary dilution was carried out with a diffusion-type perforated tube. In this tube, dilution air was introduced through small pores along the transport line to minimize losses inside the probe. The second dilution stage involved an ejector type diluter, which pulled the primary diluter sample flow. It is necessary to note that the dilution system used in this study is based on a constant dilution method. The advantage of this method is its output volume is big enough to reach $100 \mathrm{~L} \mathrm{~min}^{-1}$, which can meet the requirements for synchronous sampling of at least four channels of filters $\left(10 \mathrm{~L} \mathrm{~min}^{-1}\right.$ for each channel) and other on-line measurement instruments. Data of one set or two parallel sets of PM concentration and chemical compositions, including OC, EC, WSIs, elements, and organic matter (OM), can be obtained for one measurement. A similar method has been applied to the emission measurement of non-road machinery by Cui et al. (2017). It should be noted that proportional dilution system is more suitable to on-board emission measurement of mobile source in principle. In contrast to the proportional dilution system, which would control the dilution rate by proportionally changing the exhaust flow rate, the constant dilution system will lead to uneven sampling ratio when exhaust flow has large fluctuation. The application of constant dilution system will cause some uncertainty, underestimating the various PM compositions emission factors at high engine loads (usually with high exhaust flow) of the machines (Zheng, 2016). However, the existing proportional dilution system also have some fatal weaknesses: The flow rate of the sample gas after dilution is less than $20 \mathrm{~L} \mathrm{~min}^{-1}$, which is impossible to collect enough particles in a typical test cycle (1-2 hours) for speciated PM composition analysis; the sampling probe is likely to be clogged by soot, which would significantly influence the dilution ratio control precision (Zheng et al., 2017).

Construction machines usually possess intricate structures and limited space for installation of the measurement system. Therefore, the instruments were housed on a test platform. During the measurements, the platform was towed behind the test machine using a towing hook. Fig. 1 shows a schematic of the measurement system.

\section{Test Procedures}

Previous studies have indicated that emissions from construction machines are strongly related to the operating mode (Abolhasani et al., 2008; Frey et al., 2008; Fu et al., 2012; Cui et al., 2017; Zavala et al., 2017). To reflect the emission characteristics of machinery operated under realworld operating conditions, the measurements were performed during actual construction tasks. The excavator and wheel loader operation modes include idling, moving, 


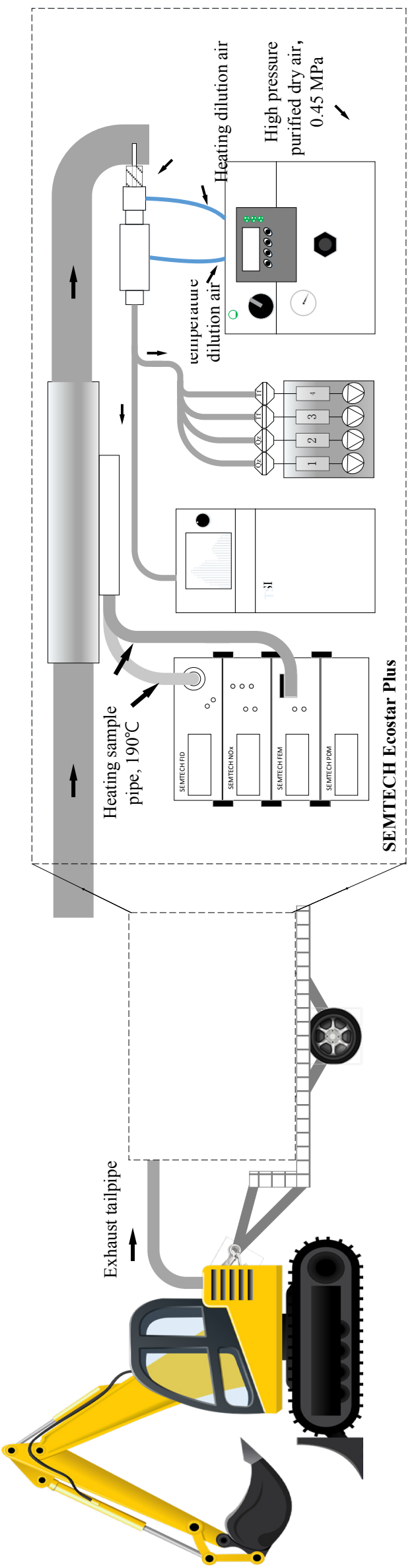

and working. The average operational time proportion of idling, moving, and working condition for the excavators accounted for $21 \pm 4 \%, 9 \pm 11 \%$, and $70 \pm 14 \%$, respectively. The tree conditions for the wheel loaders accounted for 20 $\pm 12 \%, 16 \pm 3 \%$, and $64 \pm 11 \%$, respectively. The bulldozer and roller operation modes include idling and working operating modes; idling accounted for $43 \%$ and $34 \%$ for the two machines, respectively, while working accounted for $57 \%$ and $64 \%$. The test machinery operating modes are presented in Table 1.

\section{Sampling and Analysis}

PM was sampled using four separate filter trains. Two Teflon filters (47 mm, TE 38; Whatman, UK) and two quartz filters (47 mm, QM-A; Whatman, UK) were used during each measurement period; one filter was placed in each of the four channels. The flow rate through each channel was $12 \mathrm{~L} \mathrm{~min}^{-1}$. The dilution ratios were between 16:1 and 20:1. A measurement period of $\sim 45 \mathrm{~min}$ was used to ensure sufficient particle loading on the filters. To determine PM mass, the Teflon filters were analyzed gravimetrically after equilibration for $24 \mathrm{~h}$ at $50 \pm 5 \%$ relative humidity and $20 \pm 1^{\circ} \mathrm{C}$. After gravimetric analysis, one Teflon filter was extracted and analyzed for water-soluble ions using an ion chromatograph (940 Professional IC Vario; Metrohm, Switzerland); elemental content was analyzed on the other Teflon filter using an energy-dispersive X-ray fluorescence spectrometer (Epsilon 5 EDXRF; PANalytical, Finland). $\mathrm{OC}$ and $\mathrm{EC}$ were determined on one of the quartz filters using a thermal/optical carbon analyzer (Model 2001; Desert Research Institute) and the IMPROVE-A protocol (Chow et al., 2007). OM was estimated by multiplying the measured OC by a factor of 1.2 (Turpin and Lim, 2001). The other quartz filter was analyzed for solvent-extractable organic compounds (SEOC), including $n$-alkanes, hopanes, particulate polycyclic aromatic hydrocarbons (PAHs), and $n$-fatty acids, using gas chromatographymass spectrometry (GC-MS; Agilent, USA); the analytical procedure has been described previously (Feng et al., 2007). Briefly, one fourth of the quartz filter was spiked with a surrogate mixture consisting of tetracosane- $\mathrm{d}_{50}$, chrysene- $\mathrm{d}_{12}$, anthracene- $\mathrm{d}_{10}$, perylene- $\mathrm{d}_{12}$, and heptadecanoic- $\mathrm{d}_{33}$ acid and then ultrasonically extracted in three $60 \mathrm{~mL}$ dichloromethane/methanol $(2: 1, \mathrm{~V} / \mathrm{V})$ aliquots at room temperature. The combined extract was filtered and reacted with freshly prepared diazomethane, which would not react with $\mathrm{PAH}$ and alkanes, to promote free organic acid esterification. The total extract was then analyzed via GC-MS (6890/5975 GC/MSD; Agilent, USA). Hexamethyl benzene was added prior to GC-MS analysis as an $n$-alkanol internal standard and to verify the recovery of alkanes, PAHs, and fatty acids. As shown in Table 4, $21 n$-alkanes, 10 hopanes, 21 particulate PAHs (3-5-ringed), and $21 n$-fatty acids were analyzed quantitatively by GC-MS; alkanes, PAHs, and fatty acids were quantified using deuterated internal standards with chemical characteristics and retention times similar to those of the target analytes. The MS analysis was performed at $70 \mathrm{eV}$ in electron impact mode over a mass range of $45-550 \mathrm{~m} / \mathrm{z}$. The GC, which features 
an HP-5MS capillary column $(30 \mathrm{~m} \times 0.25 \mathrm{~mm} \times 0.25 \mu \mathrm{m})$, was operated with helium carrier gas at a flow rate of $1.0 \mathrm{~mL} \mathrm{~min}{ }^{-1}$. The temperature procedures used for nonpolar and polar organic matter are same. The procedures are as follows: The oven temperature was set initially at $40^{\circ} \mathrm{C}$ and continued with 4 minutes of isothermal holding time, then increased to $120^{\circ} \mathrm{C}$ at $10^{\circ} \mathrm{C} \mathrm{min}^{-1}$ and held for 2 minutes, and finally increased to $300^{\circ} \mathrm{C}$ at $20^{\circ} \mathrm{C} \mathrm{min}^{-1}$ and held for 20 minutes. Analytes were quantified via linear regressions from five-point calibration curves between authentic-standard-to-internal-standard concentrations ratios and the corresponding peak area ratios.

The external system audits and inter-laboratory comparisons of analytical equipment were conducted to keep the QA in high level. The QC procedure in the process of sample collection and analysis were followed: The flow control valves of the particle sampling system were calibrated by a mass flow meter (Mass Flow Meter 41403; TSI Inc., USA) before each test; the quartz filter was preheated to reduce the interference, and the blank samples and other quality control samples were also included in this study to minimize the artifact effect result of OC/EC, WSIs, and OM. Full-scale calibration of the flame ionization detector and verification of trace $\mathrm{O}_{2}$ concentrations $(<100 \mathrm{ppmv})$ in the $\mathrm{He}$ analysis atmosphere were carried out before every OC/EC analysis (Chow et $a l ., 2007)$. The X-ray energy was calibrated before every elemental content analysis; the calibration verification and background determination were conducted regularly. When OM was analyzed by GC-MS, a complete analysis of blank and duplicate samples was performed for each batch of samples. If only the analysis results of the blank and duplicate samples met the requirements, the formal sample analysis would be performed. The analysis results show that the recovery rates of the organic matter of the samples ranged from $93.2 \%$ to $98.3 \%$.

\section{Data Processing}

Fuel-based gaseous, particulate matter, and particle number EFs (6.04-523 nm) were calculated using the carbon balance method, as shown in the following equations:

$$
\begin{aligned}
& E F_{\text {gaseous }_{-} i}=\frac{\Delta m_{i} \times x_{c}}{\Delta C O_{2}+\Delta C O+\Delta P M_{c}+\Delta T H C} \\
& E F_{P M}=\frac{\sum_{j=1}^{32} \Delta P M_{j} \times x_{c}}{\Delta C O_{2}+\Delta C O+\Delta P M_{c}+\Delta T H C} \\
& E F_{P N}=\frac{\sum_{j=1}^{32} \Delta P N_{j} \times x_{c}}{\Delta C O_{2}+\Delta C O+\Delta P M_{c}+\Delta T H C}
\end{aligned}
$$

where $E F_{\text {gaseous } i}$ is the fuel-based emission factor $\left(\mathrm{g} \mathrm{kg}^{-1}\right)$ of gaseous pollutant $i, E F_{P M}$ and $E F_{P N}$ are the fuel-based emission factors of PM $\left(\mathrm{g} \mathrm{kg}^{-1}\right)$ and PN $\left(\# \mathrm{~kg}^{-1}\right), \Delta m_{i}$ is the measured mass concentration of species $i$ in the exhaust gas $\left(\mathrm{mg} \mathrm{m}^{-3}\right), \triangle P M_{j}$ and $\triangle P N_{j}$ are the measured particulate matter concentration $\left(\mathrm{g} \mathrm{m}^{-3}\right)$ and particle number concentration $\left(\# \mathrm{~m}^{-3}\right)$ of the particle size channel $j$, and $x_{c}$ is the mass fraction of carbon (\%) in the diesel, which is set to be $86 \%$ in this study according to Table 2. $\Delta \mathrm{CO}_{2}$, $\Delta \mathrm{CO}, \Delta \mathrm{PM}_{c}$, and $\triangle \mathrm{THC}$ are the background-corrected carbon concentrations of $\mathrm{CO}_{2}, \mathrm{CO}$, carbonaceous $\mathrm{PM}$, and $\mathrm{THC}\left(\mathrm{gC} \mathrm{m}^{-3}\right)$.

Fuel consumption (FC) rate were calculated by carbonaceous emissions concentration and exhaust gas flow rate, as shown in the following equation:

$$
\mathrm{FC}=\frac{m_{e x}\left(\Delta \mathrm{CO}_{2}+\Delta \mathrm{CO}+\Delta \mathrm{PM}_{c}+\Delta \mathrm{THC}\right)}{\rho_{e x} x_{c}}
$$

where $\mathrm{FC}$ is the fuel consumption rate $\left(\mathrm{kg} \mathrm{h}^{-1}\right), m_{e x}$ is the exhaust gas flow rate $\left(\mathrm{kg} \mathrm{h}^{-1}\right)$, and $\rho_{e x}$ is the density of the exhaust gas $\left(\mathrm{kg} \mathrm{m}^{-3}\right)$.

\section{RESULTS AND DISCUSSION}

\section{Gaseous and Particulate Matter EFs}

The fuel-based EFs for $\mathrm{NO}_{x}, \mathrm{CO}$, THC, PM, and PN from each type of machinery are summarized along with EFs from the literature in Table 3. The $\mathrm{NO}_{\mathrm{x}}, \mathrm{CO}$, and THC EFs measured herein for the excavator agree well with results from excavators with the same emission standards (Stages 0-2 or Tiers 0-2) in previous studies (Abolhasani et al., 2008; Frey et al., 2010; Fu et al., 2012). The wheel loader $\mathrm{NO}_{\mathrm{x}}, \mathrm{CO}$, and THC EFs herein are similar to those measured by another study in China (Fu et al., 2012). The $\mathrm{NO}_{\mathrm{x}}$ EFs for the bulldozer and roller were higher than those in previous studies (Frey et al., 2010; Li et al., 2016). For various types of machines, $\mathrm{NO}_{\mathrm{x}}$ EFs showed consistent decreases under enhanced emission standards, as shown in studies by Cao et al. (2016) and Zavala et al. (2017) in the U.S. and Mexico. The PM EFs were relatively varied. The average PM EFs from the excavators, wheel loaders, bulldozer, and roller were within the range of measurements from previous studies (Abolhasani et al., 2008; Frey et al., 2010; Fu et al., 2012; Cao et al., 2017). PN EFs for the test machines, with the exception of the bulldozer, were above $10^{15} \mathrm{\#} \mathrm{kg}^{-1}$, similar to results from heavy-duty diesel vehicles without after-treatment devices (Hallquist et al., 2013; Huang et al., 2013; Ježek et al., 2015; Pirjola et al., 2016).

Fig. 2 shows fuel consumption (FC) rates and fuel-based EFs for each type of machine under different operating modes. Test machine FC rates were higher under moving and working conditions than while idling. Under working conditions in particular, the FC rates for the excavators, wheel loaders, bulldozer, and roller were 4.3, 2.1, 1.7, and 5.0 times higher than those while idling. However, the $\mathrm{NO}_{\mathrm{x}}, \mathrm{CO}$, and THC EFs for the excavators, wheel loaders, and bulldozer were generally higher while idling than under moving and working conditions, which is consistent with previous studies (Abolhasani et al., 2008; Fu et al., 2012; Li et al., 2016; Zavala et al., 2017). Unlike the 


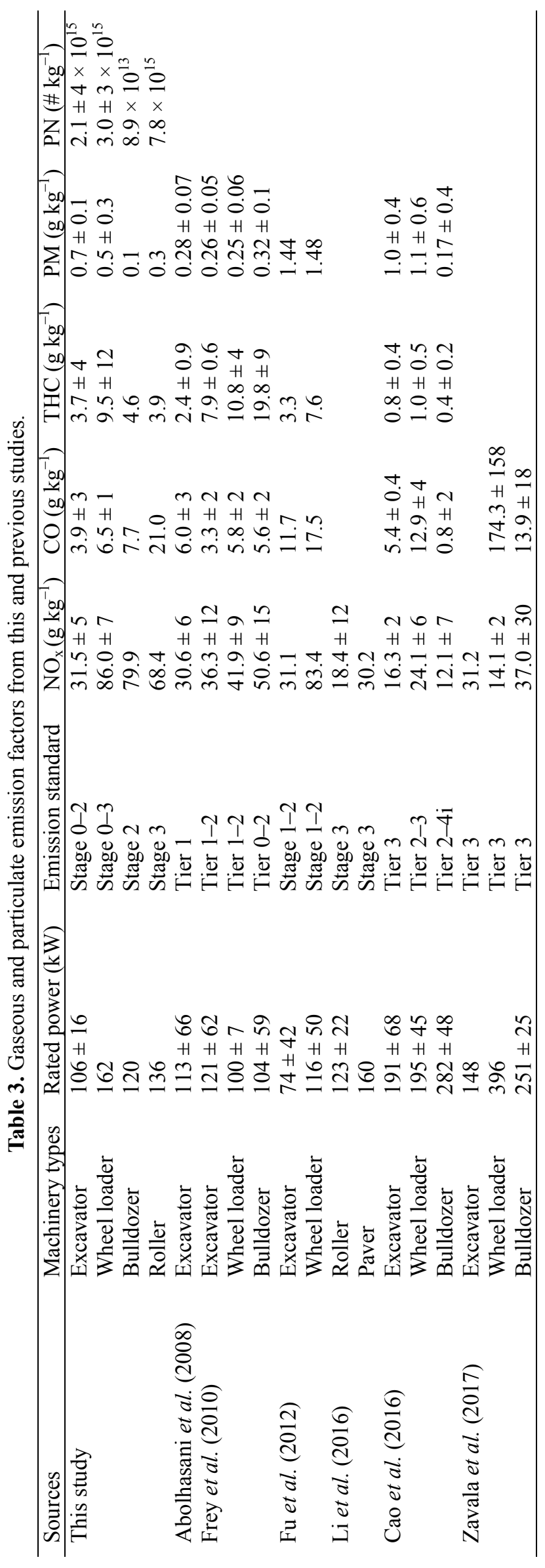

machinery above, the roller had higher EFs (for all species except THC) under working conditions than while idling. The comparison of fuel-based $\mathrm{NO}_{\mathrm{x}}, \mathrm{CO}$, and THC EFs under different operation modes are associated with pollutant concentrations and FC. As we know, $\mathrm{NO}_{\mathrm{x}}$ concentration would increase with the operation load rate rise, but when the increase rate of $\mathrm{NO}_{\mathrm{x}}$ concentration is less than the $\mathrm{FC}$ increase rate, the fuel-based $\mathrm{NO}_{\mathrm{x}} \mathrm{EF}$ will decrease; otherwise, the $\mathrm{NO}_{\mathrm{x}} \mathrm{EF}$ will rise (Moussa et al., 2016). PM EFs did not change significantly with the operating condition. For the excavators and loaders, there were no consistent changes in $\mathrm{PM}$ and PN emissions under varying operating conditions. For example, under idling conditions, the machines usually had lower PM EFs and higher PN EFs, indicating smaller particle sizes at that time; particles were larger under moving and working conditions.

\section{Speciated PM Emissions}

The speciated PM was collected and analyzed in all of the modes, and the analyzed results are representing the whole operation process. The fractional mass contributions of main category of various PM chemical components are shown in Fig. 3(a); the detailed fractions of speciated PM are summarized in Table 4. The PM filter for EX_2 was contaminated during the sampling process, so PM data is not available for this machine. OM and EC were the main PM components in the diesel construction machinery exhaust. OM accounted for $41 \pm 17 \%, 52.3 \pm 15 \%, 50.9 \%$, and $46.6 \%$ of the total PM mass for the excavator, loader, bulldozer, and roller, respectively, while EC contributed $47.2 \pm 8 \%, 34.5 \pm 15 \%, 19.6 \%$, and $37.1 \%$.

The contributions of WSIs to PM mass were relatively low, with an average of $1.9 \pm 1 \%$. WSIs from the test machines consisted primarily of $\mathrm{NO}_{3}{ }^{-}$, which accounted for $1.3 \pm 1 \%$ of the total PM mass, followed by $\mathrm{SO}_{4}{ }^{2-}$. These results are consistent with $\mathrm{Ma}$ et al. (2018). However, $\mathrm{SO}_{4}{ }^{2-}$ was the dominant contributor to PM mass, far outweighing $\mathrm{NO}_{3}{ }^{-}$, in diesel vehicle and machinery exhaust in previous studies in China (Zhang et al., 2015; Cui et al., 2017); these differences may be attributed to the diesel fuel sulfur content in these studies, which reached up to $500 \mathrm{ppm}$ and $1300 \mathrm{ppm}$, respectively. The quality of diesel fuel has improved in recent years; diesel sulfur content is currently controlled to $<50 \mathrm{ppm}$, which generally reduces the fraction of $\mathrm{SO}_{4}{ }^{2-}$ in PM emissions in diesel exhaust.

The elemental component fractions varied between the different types of machinery. Elements constituted $4.9 \pm$ $2 \%, 2.6 \pm 0.9 \%$, and $1.8 \%$ of the excavator, wheel loader, and roller emissions, respectively; $\mathrm{Si}$ was the dominant elemental component, accounting for $3.5 \pm 1.9 \%, 1.2 \pm$ $1.1 \%$, and $1.1 \%$ of the total PM mass. The elemental fraction was much higher for the bulldozer than for the other machine types, reaching $18.5 \%$ of the total PM mass. The major elements emitted from the bulldozer were $\mathrm{Si}$, $\mathrm{Ca}, \mathrm{Al}$, and $\mathrm{Fe}$, which accounted for $5.1 \%, 5.1 \%, 2.4 \%$, and $1.8 \%$, respectively, of the total PM mass. These elements are generally derived primarily from diesel fuel impurities (Wang et al., 2003). Thus, the inferior quality of the diesel fuel used in the test bulldozer may explain the high 

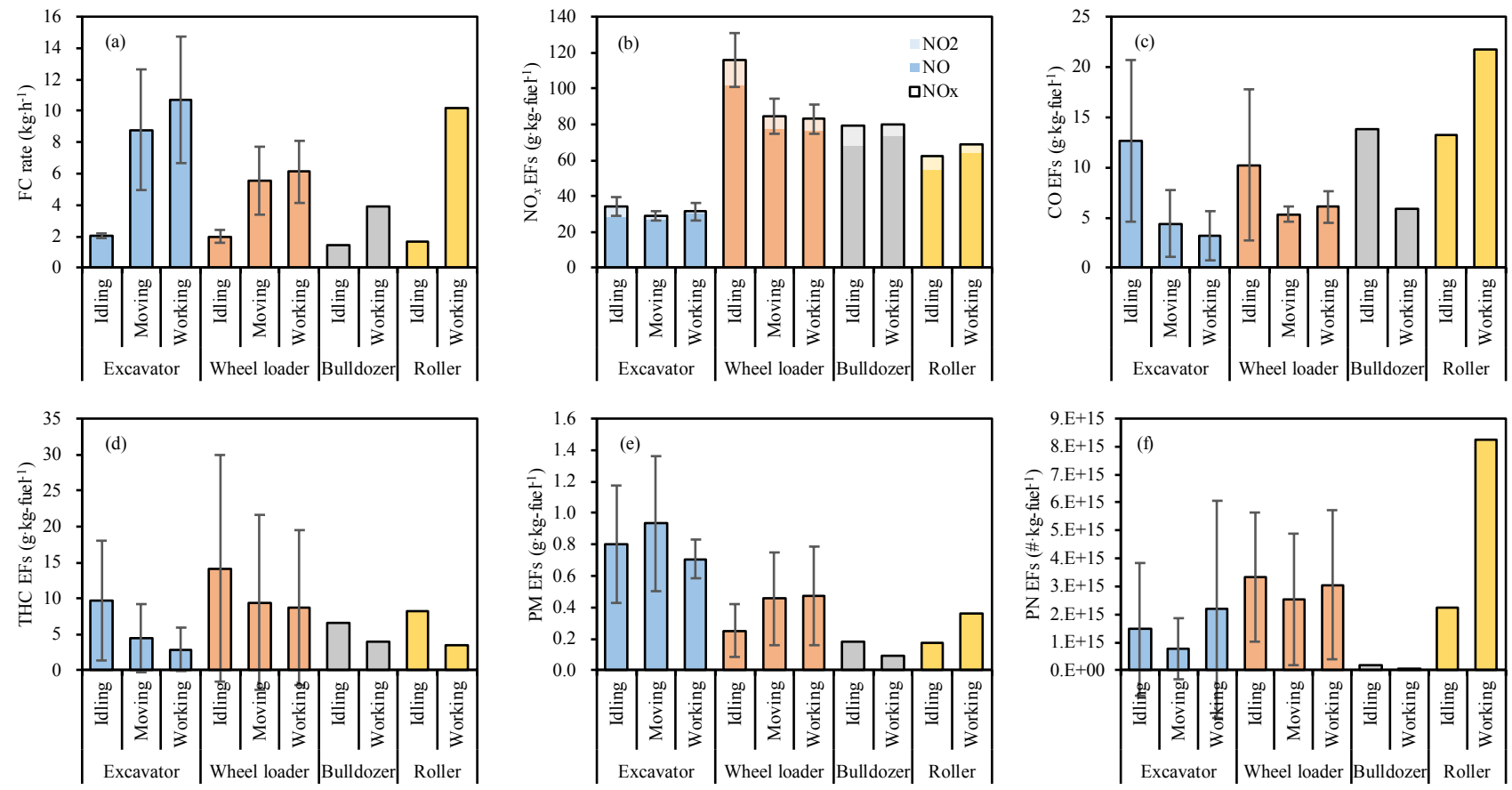

Fig. 2. (a) Average fuel consumption rates. Fuel-based EFs of (b) $\mathrm{NO}$ (dark shading), $\mathrm{NO}_{2}$ (light shading), and $\mathrm{NO}_{\mathrm{x}}$; (c) CO; (d) THC; (e) PM; and (f) PN for each machine type under different operating modes. Error bars indicate standard deviation.

elemental emissions. The $\mathrm{PM} \mathrm{SO}_{4}{ }^{2-}$ fraction emitted from the test bulldozer, which measured up to $1.2 \%$, was much higher than the $\mathrm{SO}_{4}{ }^{2-}$ fractions emitted from the other machinery types $(0.1-0.3 \%)$.

The fractional contributions of various OM species to the total PM organic mass are shown in Fig. 3(b). Altogether, $21 n$-alkanes, 10 hopanes, 21 particulate PAHs, and 21 $n$-fatty acids were quantified in the PM samples (see Table 4 ). OM species contributed approximately $2.4-6.4 \%$ of the total PM mass. $n$-Alkanes were the dominant organic component, accounting for $2.26 \pm 0.2 \%, 4.48 \pm 2 \%, 1.87 \%$, and $3.71 \%$ of the total PM mass from the excavators, wheel loaders, bulldozer, and roller, respectively; $n$-fatty acids were the second most abundant category, contributing $0.65 \pm 0.4 \%$, $0.42 \pm 0.4 \%, 1.47 \%$, and $0.71 \%$ of the total PM mass. The average PM mass fractions of hopanes and particulate PAHs were $0.049 \pm 0.03 \%$ and $0.078 \pm 0.02 \%$, respectively. Cui et al. (2017) reported $n$-alkane and particulate PAH fractions reaching $5.14 \%$ and $0.098 \%$, slightly higher than the proportions found herein; this may be attributed to the use of high-sulfur fuel in that study. The $n$-alkanes found herein consisted primarily of C18-C23 compounds, except for those emitted from the bulldozer, which contained more high-carbon components (C20-C24), as shown in Table 4. Hopanes can be used as organic tracers for oil combustion processes. $17 \mathrm{a}(\mathrm{H}) 21 \beta(\mathrm{H})$-hopane $(\mathrm{C} 30 \mathrm{H})$ and $17 \mathrm{a}(\mathrm{H}) 21 ß(\mathrm{H})-30$-norhopane $(\mathrm{C} 29 \mathrm{H})$ were the most abundant hopanes, contributing $0.016 \pm 0.01 \%$ and $0.009 \pm 0.004 \%$ of the total PM mass, respectively, which is similar to the hopane composition of PM emissions from diesel vehicles and ships (Schauer et al., 1999; Sippula et al., 2014; Cui et al., 2017).

\section{$O C$ and EC Emissions}

On average, the $\mathrm{OC}$ and $\mathrm{EC}$ measured in the test machine emissions herein contributed $39.3 \pm 11 \%$ and 37.7 $\pm 13 \%$ of the total PM mass, as shown in Fig. 4. The average $\mathrm{OC} / \mathrm{EC}$ ratio was $1.24 \pm 0.7$, which is similar to the average excavator OC/EC ratio (1.18) measured by Cui et al. (2017), lower than the ratios measured for diesel fork lifts (FL; 2.71) and generators (GE; 2.73) by Chow et al. (2011), and higher than the ratios measured in diesel truck exhaust in China (0.43-0.57; Zhang et al., 2015; Wu et al., 2016). Previous studies have indicated that engine load affects OC and EC emissions considerably (Liu et al., 2005; Wu et al., 2016; Cui et al., 2017); OC/EC ratios are much higher under low engine load, such as during idling, than under high engine load, as OC is generated predominantly at low temperatures in fuel-rich zones. The diesel trucks evaluated by Zhang et al. (2015) and Wu et al. (2016) were operated at high speed (high load), resulting in relatively low OC/EC ratios compared with construction machinery in this and previous studies (Chow et al., 2011; Cui et al., 2017).

\section{PAH Emissions}

The fuel-based EFs of the speciated PAHs were classified by the number of benzene rings, as shown in Fig. 5(a). The average fuel-based EF for the test machinery was $382 \pm$ $264 \mathrm{~g} \mathrm{~kg}$ fuel $^{-1}$. Compounds with 3 or 4 benzene rings were dominant, accounting for $34.9 \%$ and $52.3 \%$, respectively, of the total particulate PAHs. Pyrene, phenanthrene, and fluoranthene were the most abundant particulate PAH compounds emitted from the test machines, constituting $37.1 \%, 12.6 \%$, and $12.2 \%$, respectively, of the total PAHs. 

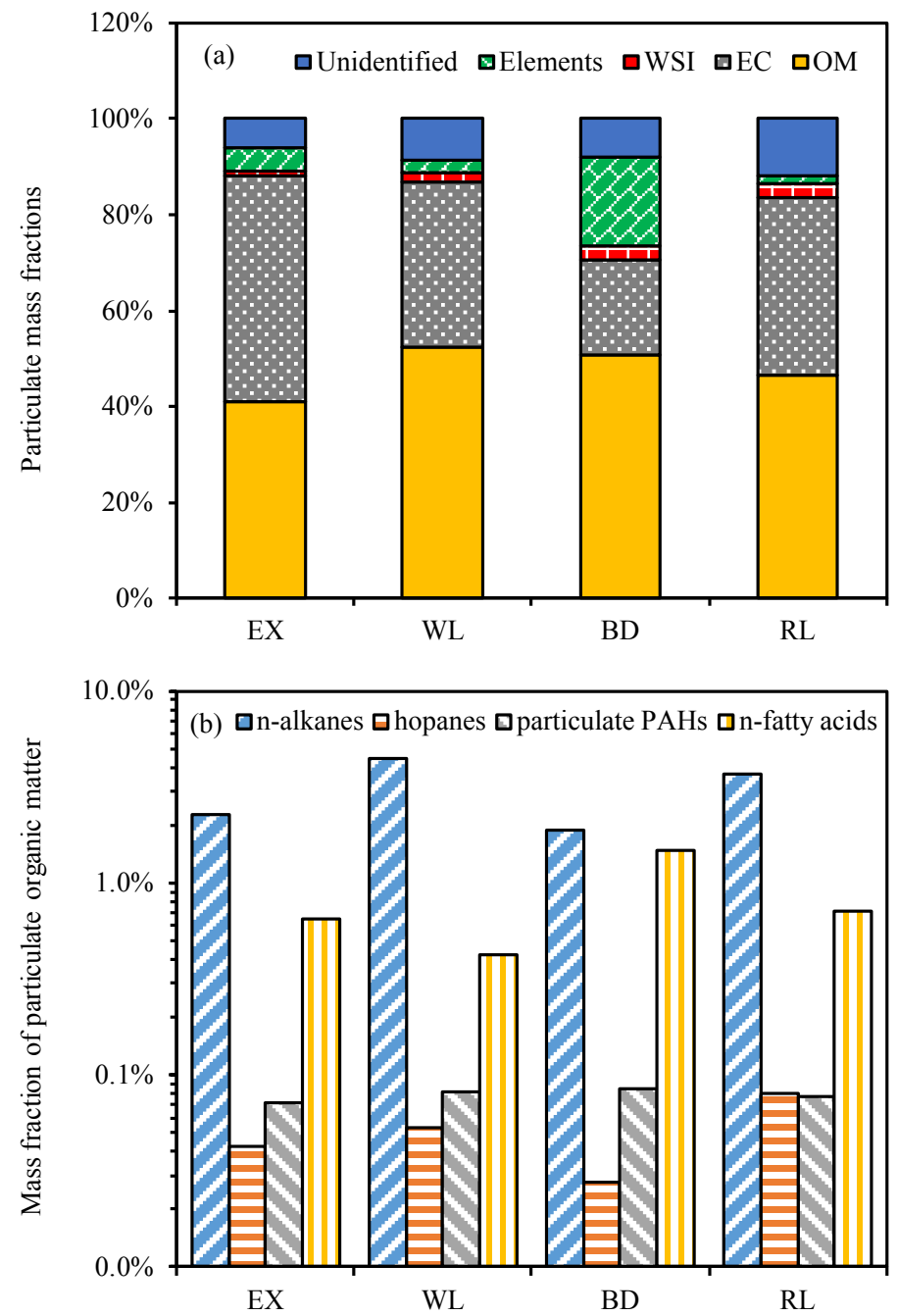

Fig. 3. (a) Fractional contributions of various species to total PM mass and (b) fractional contributions of organic matter species to total organic mass.

Table 4. Fractional chemical and organic matter of PM composition for each test machine (\%).

\begin{tabular}{|c|c|c|c|c|c|c|c|c|}
\hline Species & EX_1 & EX 3 & EX 4 & WL_1 & WL_ 2 & WL_3 & BD_1 & RL 1 1 \\
\hline $\mathrm{OC}$ & 19.6 & 47.9 & 35 & 57.9 & 37.9 & 34.9 & 42.4 & 38.8 \\
\hline EC & 47.1 & 36.2 & 34.7 & 19.7 & 43 & 23.6 & 16.4 & 30.9 \\
\hline $\mathrm{SO}_{4}{ }^{2-}$ & 0.1 & 0.2 & 0.2 & 0.3 & 0.1 & 0.2 & 1.2 & 0.3 \\
\hline $\mathrm{NO}_{3}^{-}$ & 0.5 & 0.0 & 1.6 & 1.8 & 1.8 & 1.4 & 1.3 & 2.1 \\
\hline $\mathrm{Cl}^{-}$ & 0.0 & 0.1 & 0.1 & 0.4 & 0.2 & 0.0 & 0.3 & 0.2 \\
\hline $\mathrm{NH}_{4}^{+}$ & 0.0 & 0.0 & 0.0 & 0.1 & 0.0 & 0.1 & 0.0 & 0.2 \\
\hline ¿WSIs & 0.6 & 0.3 & 1.9 & 2.6 & 2.1 & 1.7 & 2.9 & 2.7 \\
\hline $\mathrm{Na}$ & 0.1 & 0.0 & 0.2 & 0.2 & 0.2 & 0.4 & 1.2 & 0.0 \\
\hline $\mathrm{Mg}$ & 0.5 & 0.0 & 0.3 & 0.0 & 0.1 & 0.0 & 0.0 & 0.0 \\
\hline $\mathrm{Al}$ & 0.8 & 0.5 & 0.8 & 0.4 & 0.5 & 0.0 & 2.4 & 0.3 \\
\hline $\mathrm{Si}$ & 3.6 & 1.5 & 5.3 & 0.4 & 2.5 & 0.6 & 5.1 & 1.2 \\
\hline $\mathrm{K}$ & 0.1 & 0.0 & 0.0 & 0.0 & 0.0 & 0.3 & 1.0 & 0.0 \\
\hline $\mathrm{Ca}$ & 0.1 & 0.1 & 0.0 & 0.2 & 0.1 & 0.6 & 5.1 & 0.2 \\
\hline $\mathrm{Ti}$ & 0.0 & 0.0 & 0.0 & 0.0 & 0.0 & 0.0 & 0.1 & 0.0 \\
\hline V & 0.0 & 0.0 & 0.0 & 0.0 & 0.0 & 0.0 & 0.0 & 0.0 \\
\hline $\mathrm{Cr}$ & 0.0 & 0.0 & 0.0 & 0.0 & 0.0 & 0.0 & 0.0 & 0.0 \\
\hline $\mathrm{Mn}$ & 0.0 & 0.0 & 0.0 & 0.0 & 0.0 & 0.0 & 0.1 & 0.0 \\
\hline $\mathrm{Fe}$ & 0.1 & 0.1 & 0.0 & 0.1 & 0.1 & 0.2 & 1.8 & 0.0 \\
\hline ¿Elements & 5.3 & 2.4 & 7.0 & 1.7 & 3.5 & 2.5 & 18.5 & 1.8 \\
\hline
\end{tabular}


Table 4. (continued).

\begin{tabular}{|c|c|c|c|c|c|c|c|c|}
\hline Species & EX 1 & EX 3 & EX 4 & WL 1 & WL 2 & WL 3 & BD 1 & RL 1 \\
\hline $\mathrm{C}_{16} \mathrm{H}_{34}$ & 0.0 & 0.0 & 0.1 & 0.1 & 0.0 & 0.0 & 0.0 & 0.0 \\
\hline $\mathrm{C}_{17} \mathrm{H}_{36}$ & 0.1 & 0.0 & 0.1 & 0.3 & 0.1 & 0.0 & 0.0 & 0.0 \\
\hline $\mathrm{C}_{18} \mathrm{H}_{38}$ & 0.2 & 0.1 & 0.3 & 0.7 & 0.2 & 1.2 & 0.0 & 0.3 \\
\hline $\mathrm{C}_{19} \mathrm{H}_{40}$ & 0.4 & 0.3 & 0.5 & 1.1 & 0.4 & 1.6 & 0.1 & 0.7 \\
\hline $\mathrm{C}_{20} \mathrm{H}_{42}$ & 0.4 & 0.6 & 0.4 & 1.2 & 0.4 & 1.1 & 0.2 & 0.9 \\
\hline $\mathrm{C}_{21} \mathrm{H}_{44}$ & 0.4 & 0.5 & 0.3 & 0.9 & 0.3 & 0.7 & 0.4 & 0.7 \\
\hline $\mathrm{C}_{22} \mathrm{H}_{46}$ & 0.3 & 0.3 & 0.2 & 0.6 & 0.2 & 0.4 & 0.4 & 0.4 \\
\hline $\mathrm{C}_{23} \mathrm{H}_{48}$ & 0.2 & 0.2 & 0.1 & 0.4 & 0.1 & 0.2 & 0.3 & 0.3 \\
\hline $\mathrm{C}_{24} \mathrm{H}_{50}$ & 0.1 & 0.1 & 0.1 & 0.2 & 0.1 & 0.1 & 0.3 & 0.1 \\
\hline $\mathrm{C}_{25} \mathrm{H}_{52}$ & 0.1 & 0.0 & 0.1 & 0.1 & 0.0 & 0.1 & 0.1 & 0.1 \\
\hline $\mathrm{C}_{26} \mathrm{H}_{54}$ & 0.1 & 0.0 & 0.0 & 0.0 & 0.0 & 0.1 & 0.1 & 0.0 \\
\hline $\mathrm{C}_{27} \mathrm{H}_{56}$ & 0.0 & 0.0 & 0.0 & 0.0 & 0.0 & 0.0 & 0.0 & 0.0 \\
\hline $\mathrm{C}_{28} \mathrm{H}_{58}$ & 0.0 & 0.0 & 0.0 & 0.0 & 0.0 & 0.0 & 0.0 & 0.0 \\
\hline $\mathrm{C}_{29} \mathrm{H}_{60}$ & 0.0 & 0.0 & 0.0 & 0.0 & 0.0 & 0.0 & 0.0 & 0.0 \\
\hline $\mathrm{C}_{30} \mathrm{H}_{62}$ & 0.0 & 0.0 & 0.0 & 0.0 & 0.0 & 0.0 & 0.0 & 0.0 \\
\hline $\mathrm{C}_{31} \mathrm{H}_{64}$ & 0.0 & 0.0 & 0.0 & 0.0 & 0.0 & 0.0 & 0.0 & 0.0 \\
\hline $\mathrm{C}_{32} \mathrm{H}_{66}$ & 0.0 & 0.0 & 0.0 & 0.0 & 0.0 & 0.0 & 0.0 & 0.0 \\
\hline $\mathrm{C}_{33} \mathrm{H}_{68}$ & 0.0 & 0.0 & 0.0 & 0.0 & 0.0 & 0.0 & 0.0 & 0.0 \\
\hline $\mathrm{C}_{34} \mathrm{H}_{70}$ & 0.0 & 0.0 & 0.0 & 0.0 & 0.0 & 0.0 & 0.0 & 0.0 \\
\hline $\mathrm{C}_{35} \mathrm{H}_{72}$ & 0.0 & 0.0 & 0.0 & 0.0 & 0.0 & 0.0 & 0.0 & 0.0 \\
\hline $\mathrm{C}_{36} \mathrm{H}_{74}$ & 0.0 & 0.0 & 0.0 & 0.0 & 0.0 & 0.0 & 0.0 & 0.0 \\
\hline$\Sigma n$-alkanes & 2.5 & 2.2 & 2.2 & 5.5 & 1.9 & 6.0 & 1.9 & 3.7 \\
\hline Ts & 0.002 & 0.002 & 0.005 & 0.004 & 0.002 & 0.009 & 0.002 & 0.005 \\
\hline $\mathrm{Tm}$ & 0.002 & 0.001 & 0.004 & 0.003 & 0.002 & 0.006 & 0.002 & 0.005 \\
\hline $\mathrm{C} 29 \mathrm{H}$ & 0.006 & 0.006 & 0.015 & 0.009 & 0.006 & 0.014 & 0.005 & 0.010 \\
\hline ba-C29H & 0.000 & 0.000 & 0.001 & 0.000 & 0.001 & 0.002 & 0.002 & 0.001 \\
\hline $\mathrm{C} 30 \mathrm{H}$ & 0.009 & 0.009 & 0.025 & 0.009 & 0.011 & 0.032 & 0.008 & 0.028 \\
\hline ba-C30H & 0.001 & 0.001 & 0.003 & 0.001 & 0.001 & 0.005 & 0.001 & 0.004 \\
\hline C31H-S & 0.003 & 0.003 & 0.006 & 0.005 & 0.000 & 0.011 & 0.003 & 0.010 \\
\hline C31H-R & 0.002 & 0.002 & 0.005 & 0.002 & 0.000 & 0.007 & 0.002 & 0.006 \\
\hline $\mathrm{C} 32 \mathrm{H}-\mathrm{S}$ & 0.002 & 0.002 & 0.004 & 0.002 & 0.000 & 0.009 & 0.002 & 0.006 \\
\hline C32H-R & 0.001 & 0.001 & 0.003 & 0.001 & 0.000 & 0.006 & 0.001 & 0.005 \\
\hline ¿hopanes & 0.03 & 0.03 & 0.07 & 0.03 & 0.02 & 0.10 & 0.03 & 0.08 \\
\hline Phenanthrene & 0.022 & 0.004 & 0.009 & 0.005 & 0.019 & 0.009 & 0.003 & 0.008 \\
\hline Anthracene & 0.002 & 0.001 & 0.001 & 0.001 & 0.002 & 0.001 & 0.001 & 0.001 \\
\hline Fluoranthene & 0.017 & 0.010 & 0.005 & 0.008 & 0.007 & 0.012 & 0.009 & 0.009 \\
\hline Acephenanthrene & 0.004 & 0.002 & 0.001 & 0.002 & 0.002 & 0.003 & 0.001 & 0.002 \\
\hline Retene & 0.002 & 0.002 & 0.001 & 0.002 & 0.001 & 0.002 & 0.001 & 0.001 \\
\hline Pyrene & 0.039 & 0.021 & 0.021 & 0.038 & 0.028 & 0.036 & 0.014 & 0.035 \\
\hline Benzo[ghi]fluoranthene & 0.004 & 0.001 & 0.001 & 0.002 & 0.001 & 0.002 & 0.005 & 0.002 \\
\hline Cyclopenta $[c d]$ pyrene & 0.001 & 0.000 & 0.000 & 0.001 & 0.000 & 0.001 & 0.001 & 0.001 \\
\hline Benz $[a]$ anthracene & 0.002 & 0.001 & 0.001 & 0.001 & 0.001 & 0.002 & 0.003 & 0.001 \\
\hline Chrysene & 0.004 & 0.002 & 0.001 & 0.002 & 0.002 & 0.003 & 0.006 & 0.002 \\
\hline Benzo $[b+k]$ fluoranthene & 0.004 & 0.001 & 0.003 & 0.007 & 0.004 & 0.003 & 0.009 & 0.002 \\
\hline Benzo $[a]$ fluoranthene & 0.000 & 0.000 & 0.000 & 0.001 & 0.000 & 0.001 & 0.001 & 0.001 \\
\hline 1,3,5-triphenylbenzene & 0.000 & 0.000 & 0.000 & 0.000 & 0.000 & 0.000 & 0.002 & 0.001 \\
\hline Benzo[e]pyrene & 0.003 & 0.001 & 0.001 & 0.002 & 0.003 & 0.003 & 0.006 & 0.002 \\
\hline Benzo $[a]$ pyrene & 0.002 & 0.001 & 0.002 & 0.002 & 0.000 & 0.002 & 0.003 & 0.002 \\
\hline Perylene & 0.000 & 0.000 & 0.000 & 0.001 & 0.000 & 0.000 & 0.000 & 0.000 \\
\hline Anthanthracene & 0.001 & 0.000 & 0.000 & 0.001 & 0.000 & 0.002 & 0.003 & 0.001 \\
\hline Benzo[123-cd]pyrene & 0.002 & 0.000 & 0.001 & 0.002 & 0.000 & 0.003 & 0.004 & 0.001 \\
\hline Dibenz $[a h]$ anthracene & 0.000 & 0.000 & 0.000 & 0.000 & 0.000 & 0.001 & 0.001 & 0.000 \\
\hline Benzo[ghi]perylene & 0.005 & 0.001 & 0.002 & 0.003 & 0.001 & 0.005 & 0.009 & 0.003 \\
\hline Coronene & 0.001 & 0.000 & 0.001 & 0.001 & 0.001 & 0.001 & 0.002 & 0.000 \\
\hline ¿particulate PAHs & 0.12 & 0.05 & 0.05 & 0.08 & 0.07 & 0.09 & 0.09 & 0.08 \\
\hline$\Sigma$ fatty acids & 0.4 & 1.1 & 0.5 & 0.8 & 0.4 & 0.1 & 1.5 & $\mathbf{0 . 7}$ \\
\hline
\end{tabular}




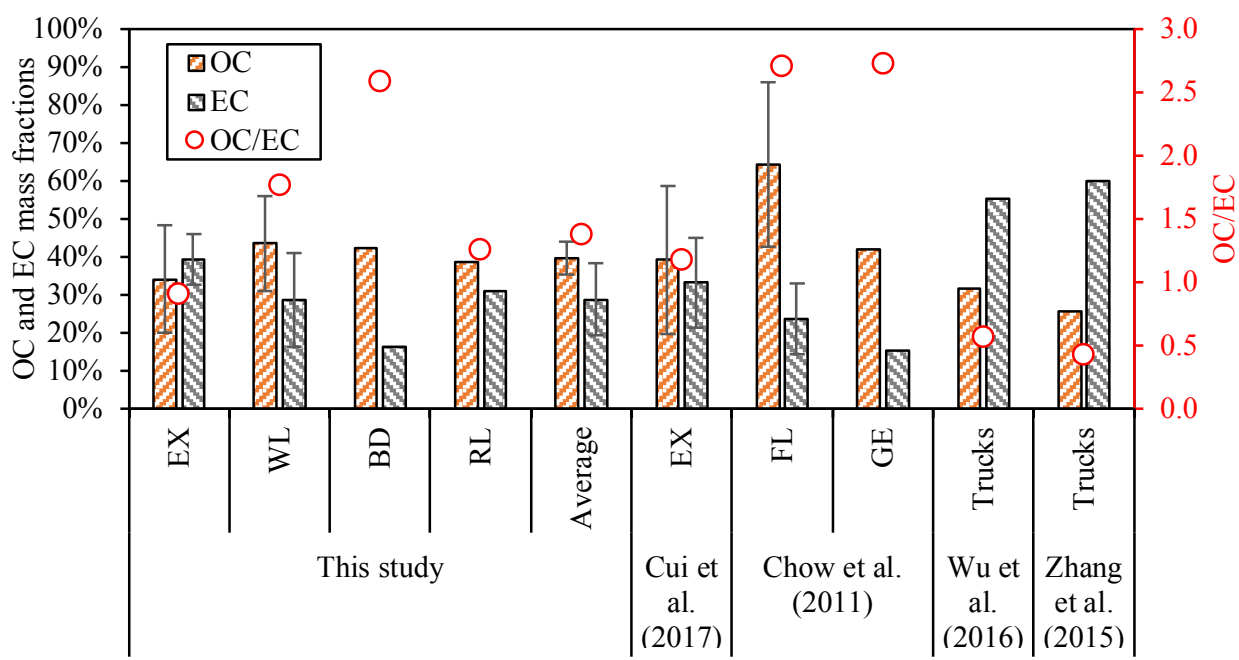

Fig. 4. OC and EC mass fractions and OC/EC ratios for emissions from different types of machinery in this study and in previous studies on construction machinery and diesel trucks in China.
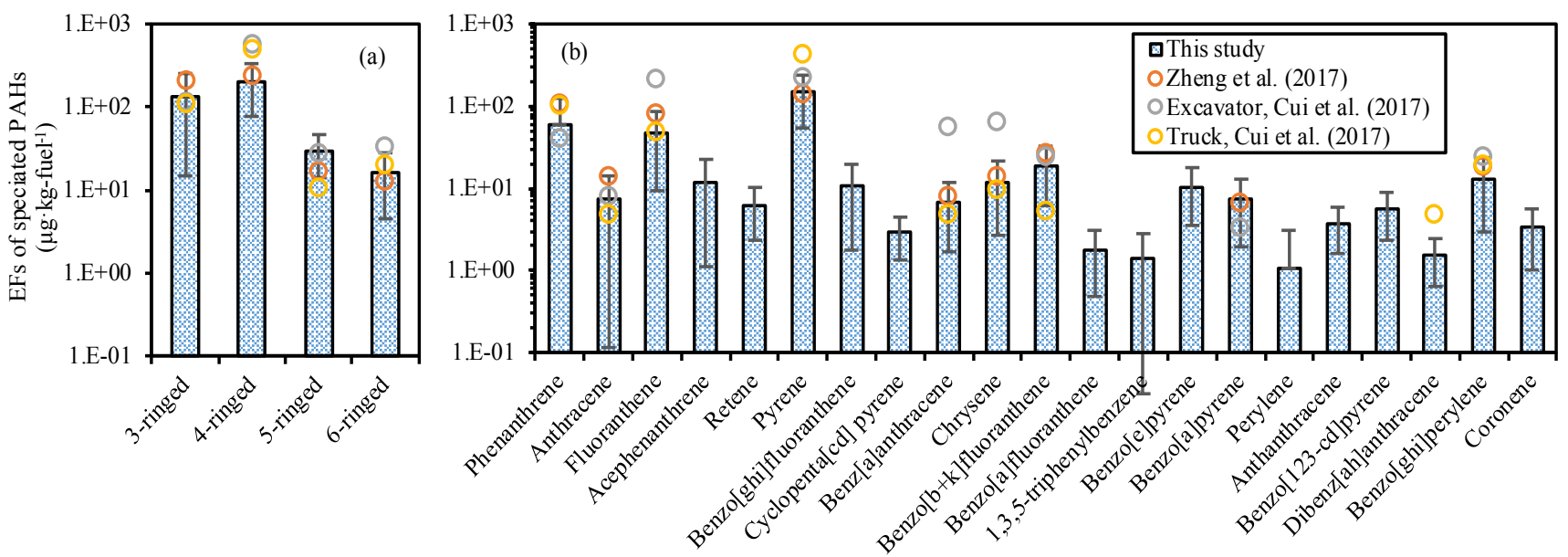

Fig. 5. Fuel-based EFs for speciated PAHs classified by (a) the number of benzene rings and (b) the speciated components, as compared with previous studies in China.

Other important compounds included benzo[ $b+k]$ fluoranthene $(\mathrm{BbkF})$, benzo[ghi]perylene (BghiP), chrysene (Chr), benzo[e]pyrene (BeP), and benzo[ghi]fluoranthene (BghiF). The distributions of individual particulate PAH species, as well as compounds with given numbers of rings, were consistent with previous studies on diesel excavators (Cui et al., 2017) and trucks (Cui et al., 2017; Zheng et al., 2017) in China, as shown in Fig. 5.

Molecular diagnostic ratios (MDRs), which consist of ratios of two individual PAHs, have been used as organic markers for various anthropogenic sources (Katsoyiannis et al., 2011) and can also be used in primary organic aerosol source apportionment (Shrivastava et al., 2007). MDRs consisting of common PAHs, e.g., fluoranthene/(pyrene + fluoranthene) $[\mathrm{Flu} /(\mathrm{Pyr}+\mathrm{Flu})]$, anthracene/(phenanthrene + anthracene) $[$ Ant/(Phe + Ant) $]$, benzo[ $[a]$ anthracene/(chrysene + benzo[a]anthracene) $[\mathrm{BaA} /(\mathrm{Chr}+\mathrm{BaA})]$, and Benzo $[a]$ pyrene/Benzo[ghi]perylene $[\mathrm{BaP} / \mathrm{BghiP}]$, have been used to estimate source contributions from diesel exhaust, as shown in Table 5. The overall Flu/(Pyr + Flu) ratio in this study was $0.25 \pm 0.07$, similar to values reported by Shah et al. (2005) and Pakbin et al. (2009), but lower than those reported by Schauer et al. (1999), Cui et al. (2017), and Zheng et al. (2017). Katsoyiannis et al. (2011) suggested that Flu/(Pyr + Flu) MDRs between 0.40 and 0.50 represent pyrogenic sources (e.g., fuel combustion). Yunker et al. (2002) and Ravindra et al. (2008) found that $\mathrm{Flu} /(\mathrm{Pyr}+\mathrm{Flu}) \mathrm{MDRs}$ of $0.39 \pm 0.1$ and $>0.5$, respectively, could be used to distinguish diesel combustion sources. Our measurements indicate much lower thresholds than those recommended by previous studies, which may introduce substantial uncertainties in the use of these ratios to infer diesel combustion sources. The average Ant/(Phe + Ant $)$ and $\mathrm{BaA} /(\mathrm{Chr}+\mathrm{BaA})$ ratios in this study were $0.12 \pm$ 0.02 and $0.36 \pm 0.02$, which are both similar to the recommended MDR lower limits ( 0.1 and 0.35 ) used to identify fuel combustion sources in Katsoyiannis et al. (2011). The MDR results herein are similar to measurements in Zheng et al. (2017) but lower than those reported by 


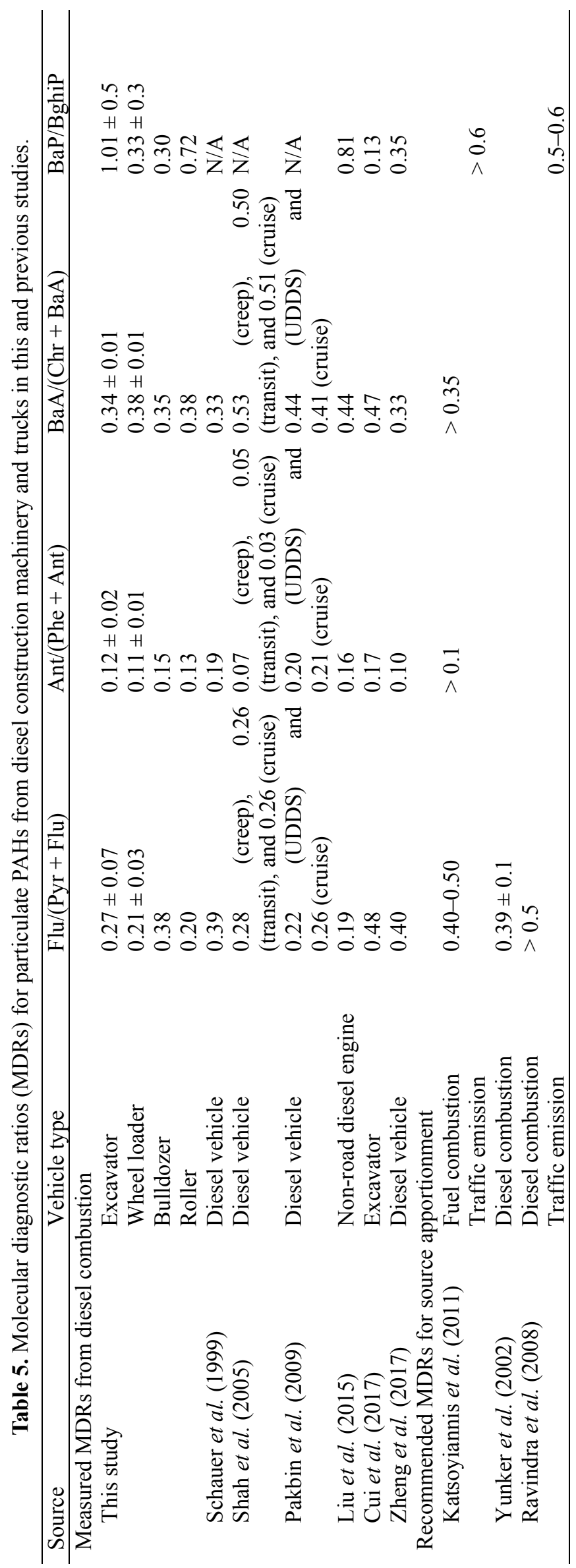


Pakbin et al. (2009), Liu et al. (2015), and Cui et al. (2017). The overall $\mathrm{BaP} / \mathrm{BghiP}$ ratio in this study was 0.63 \pm 0.5 on average, comparable to the MDR $(>0.6)$ suggested for traffic emission sources by Katsoyiannis et al. (2011) and the range (0.5-0.6) suggested by Ravindra et al. (2008). The organic markers emitted from diesel machinery and vehicles varied widely with vehicle type, fuel quality, operating mode, and control technology, as shown in Table 5. In addition, the markers recommended in previous studies cannot be used to distinguish on-road emissions from nonroad diesel exhaust. Therefore, we suggest that organic markers be applied carefully during diesel emissions source apportionment until additional real-world PAH emissions data can be obtained for on- and non-road diesel vehicles.

\section{CONCLUSIONS}

This study presents the detailed EFs and PM chemical component measurements from an on-board emission measurement system for nine diesel construction machines in China. The $\mathrm{NO}_{\mathrm{x}}, \mathrm{CO}, \mathrm{THC}, \mathrm{PM}$, and PN EFs and the fractional contributions of PM components (including OC, EC, WSIs, elements, and OM) were determined for each test machine under real-world conditions, i.e., during idling, moving, and working. The particulate and gaseous EFs were generally consistent with those found in previous studies. Although the fuel-based EFs were slightly lower while the machines were moving and working than while they were idling, the FC rates were much higher-with prominent overall emissions - during the first two conditions. Due to the lag in emission standards, the diesel construction machines displayed high EFs compared with newer machinery (manufactured according to more stringent standards). OC was the most abundant particulate component, contributing $39.3 \pm 11 \%$ of the total PM mass, followed by EC, which accounted for $37.7 \pm 13 \%$ on average. The WSIs and elements formed $1.9 \pm 1 \%$ and $5.3 \pm 6 \%$ on average of the emissions, respectively, and $\mathrm{NO}_{3}{ }^{-}$was the most abundant WSI, whereas Si dominated the elemental content. Higherquality fuel decreased the emission of WSIs and elements, with $\mathrm{SO}_{4}{ }^{2-}, \mathrm{Si}, \mathrm{Ca}, \mathrm{Al}$, and $\mathrm{Fe}$ being emitted in higher quantities from machinery powered by inferior diesel fuel. Organic matter, including $n$-alkanes, hopanes, particulate PAHs, and $n$-fatty acids, contributed approximately $2.4-6.4 \%$ of the total PM mass. Compounds with 3 or 4 aromatic rings, including pyrene, phenanthrene, and fluoranthene, were dominant, accounting for $62 \%$ of the total particulate PAHs. Other major compounds included benzo $[b+k]$ fluoranthene, benzo[ghi]perylene, chrysene, benzo[e]pyrene, and benzo[ghi]fluoranthene. The emissions from the test machines exhibited overall ratios of $0.25 \pm$ $0.07,0.12 \pm 0.02,0.36 \pm 0.02$, and $0.63 \pm 0.5$ for $\mathrm{Flu} /(\mathrm{Pyr}$ + Flu), Ant/(Phe + Ant), BaA/(Chr + BaA), and BaP/BghiP, respectively. Although the ratio of Flu/(Pyr + Flu $)$ was not consistent with the MDRs determined in previous studies, the other ratios were comparable. More measurements are necessary in order to identify organic markers of non-road diesel machinery.

\section{ACKNOWLEDGMENTS}

This work was supported by the National Key R\&D Program of China (Grant No. 2016YFC0201501), the National Natural Science Foundation of China (Grant No. 21777101), the Science and Technology Commission of Shanghai Municipality Fund Project (Grant No. 16dz1206704).

\section{REFERENCES}

Abolhasani, S., Frey, H.C., Kim, K., Rasdorf, W., Lewis, P. and Pang, S. (2008). Real-world in-use activity, fuel use, and emissions for nonroad construction vehicles: A case study for excavators. J. Air Waste Manage. Assoc. 58: $1033-1046$.

Ayhan, D. (2009). Political, economic and environmental impacts of biofuels: A review. Appl. Energy 86: S108S117.

Campbell, P., Zhang, Y., Yan, F., Lu, Z.F. and Streets, D. (2018a). Impacts of transportation sector emissions on future U.S. air quality in a changing climate. Part I: Projected emissions, simulation design, and model evaluation. Atmos. Environ. 238: 903-917.

Campbell, P., Zhang, Y., Yan, F., Lu, Z.F. and Streets, D. (2018b). Impacts of transportation sector emissions on future U.S. air quality in a changing climate. Part II: Air quality projections and the interplay between emissions and climate change. Atmos. Environ. 238: 918-930.

Cao, T., Durbin, T.D., Russell, R.L., Cocker III, D.R., Scora, G., Maldonado, H. and Johnson, K.C. (2016). Evaluations of in-use emission factors from off-road construction equipment. Atmos. Environ. 147: 234-245.

Cao T., Russell, R.L., Durbin, T.D., Cocker III, D.R., Burnette, A., Calavita, J., Maldonado, H. and Johnson, K.C. (2018). Characterization of the emissions impacts of hybrid excavators with a portable emissions measurement system (PEMS)-based methodology. Sci. Total Environ. 632: 112-119.

Chow, J.C., Watson, J.G., Chen, L.W.A., Chang, M.C.O., Robinson, N.F., Trimble, D. and Kohl, S. (2007). The IMPROVE_A temperature protocol for thermal/optical carbon analysis: Maintaining consistency with a longterm database. J. Air Waste Manage. Assoc. 57: 10141023.

Chow, J.C., Watson, J.G., Green, M.C., Wang, X.L., Chen, L.W.A., Trimble, D.L., Cropper, P.M., Kohl, S.D. and Gronstal, S.B. (2018). Separation of brown carbon from black carbon for IMPROVE and Chemical Speciation Network $\mathrm{PM}_{2.5}$ samples. J. Air Waste Manage. Assoc. 68: 494-510.

Cui, M., Chen, Y.J., Feng, Y.L., Li, C., Zheng, J.Y., Tian, C.G., Yan, C.Q. and Zheng, M. (2017). Measurement of $\mathrm{PM}$ and its chemical composition in real-world emissions from non-road and on-road diesel vehicles. Atmos. Chem. Phys. 17: 6779-6795.

Feng, J.L., Guo, Z.G., Chan, C.K. and Fang, M. (2007). Properties of organic matter in $\mathrm{PM}_{2.5}$ at Changdao Island, China-A rural site in the transport path of the 
Asian continental outflow. Atmos. Environ. 41: 19241935.

Frey, H.C., Kangwook, K., Pang, H.S., Rasdorf, W. and Lewis, P. (2008). Characterization of real-world activity, fuel use, and emissions for selected motor graders fueled with petroleum diesel and B20 biodiesel. J. Air Waste Manage. Assoc. 58: 1274-1284.

Frey, H.C., Rasdorf, W. and Lewis, P. (2010). Comprehensive field study of fuel use and emissions of nonroad diesel construction equipment. Transp. Res. Rec. 2158: 69-76.

Fu, M.L., Ge, Y.S., Tan, J.W., Zeng, T. and Liang, B. (2012). Characteristics of typical non-road machinery emissions in China by using portable emission measurement system. Sci. Total Environ. 437: 255-261.

Hallquist, Å.M., Jerksjö, M., Fallgren, H., Westerlund, J. and Sjödin, $\AA$. (2013). Particle and gaseous emissions from individual diesel and CNG buses. Atmos. Chem. Phys. 13: 5337-5350.

Huang, C., Lou, D.M., Hu, Z.Y., Feng, Q., Chen, Y.R., Chen, C.H., Tan, P.Q. and Yao, D. (2013). A PEMS study of the emissions of gaseous pollutants and ultrafine particles from gasoline- and diesel-fueled vehicles. Atmos. Environ. 77: 703-710.

IARC (International Agency for Research on Cancer) (2012). IARC: Diesel engine exhaust carcinogenic, World Health Organization, Press Release.

Ježek, I., Katrašnik, T., Westerdahl, D. and Močnik, G. (2015). Black carbon, particle number concentration and nitrogen oxide emission factors of random in-use vehicles measured with the on-road chasing method. Atmos. Chem. Phys. 15: 11011-11026.

Katsoyiannis, A., Sweetman, A.J. and Jones, K.C. (2011). PAH molecular diagnostic ratios applied to atmospheric sources: A critical evaluation using two decades of source inventory and air concentration data from the UK. Environ. Sci. Technol. 45: 8897-8906.

Li, Y.G., Huang, H.X.H., Griffith, S.M., Wu, C., Lau, A.K.H. and Yu, J.Z. (2017). Quantifying the relationship between visibility degradation and $\mathrm{PM}_{2.5}$ constituents at a suburban site in Hong Kong: Differentiating contributions from hydrophilic and hydrophobic organic compounds. Sci. Total Environ. 575: 1571-1581.

Li, Z., Zhang, K.S., Pang, K.L. and Di, B.F. (2016). A fuel-based approach for emission factor development for highway paving construction equipment in China. J. Air Waste Manage. Assoc. 66: 1214-1223.

Lindgren, M., Arrhenius, K., Larsson, G., Bäfver, L., Arvidsson, H., Wetterberg, C., Hansson, P. and Rosell, L. (2011). Analysis of unregulated emissions from an off-road diesel engine during realistic work operations. Atmos. Environ. 45: 5394-5398.

Liu, Z.F., Lu, M.M., Birch, M.E., Keener, T.C., Khang, S.J. and Liang, F.Y. (2005). Variations of the particulate carbon distribution from a nonroad diesel generator. Environ. Sci. Technol. 39: 7840-7844.

Liu, Z.G., Wall, J.C., Ottinger, N.A. and McGuffin, D. (2015). Mitigation of PAH and nitro-PAH emissions from nonroad diesel engines. Environ. Sci. Technol. 49:
3662-3671.

Lu, J., Huang, C., Hu Q.Y., Yang, Q., Jing, B.L., Xia, Y., Lu, B., Tang, W., Lou, S.R., Tao, S.K. and Li, L. (2017). Air pollutant emission inventory of non-road machineries in typical cities in Eastern China. Environ. Sci. 38: 110 118. (in Chinese)

Ma, C.Y., Zhuang, T., Zhang, Z.Y., Wang, J., Yang, F., Qiao, C. and Lu, M.M. (2018). Tailpipe emission characteristics of $\mathrm{PM}_{2.5}$ from selected on-road China III and China IV diesel vehicles. Aerosol Sci. Technol. 52: 799-808.

McDonald, B.C., Goldstein, A.H. and Harley, R.A. (2015). Long-term trends in California mobile source emissions and ambient concentrations of black carbon and organic aerosol. Environ. Sci. Technol. 49: 5178-5188.

MEP (Ministry of Environmental Protection of China) (2018). China vehicle environmental management annual report 2018. Vehicle Emission Control Center of MEP, Beijing, 43.

Mohankumara, S. and Senthilkumar, P. (2017). Particulate matter formation and its control methodologies for diesel engine: A comprehensive review. Renewable Sustainable Energy Rev. 80: 1227-1238.

Moussa, S.G., Leithead, A., Li, S.M., Chan, T.W., Wentzell, J.J.B., Stroud, C., Zhang, J., Lee, P., Lu, G., Brook, J.R., Hayden, K., Narayan, J. and Liggio, J. (2016). Emissions of hydrogen cyanide from on-road gasoline and diesel vehicles. Atmos. Environ. 131: 185-195.

Pakbin, P., Ning, Z., Schauer, J.J. and Sioutas, C. (2009). Characterization of particle bound organic carbon from diesel vehicles equipped with advanced emission control technologies. Environ. Sci. Technol. 43: 4679-4686.

Pirjola, L., Dittrich, A., Niemi, J.V., Saarikoski, S., Timonen, H., Kuuluvainen, H., Järvinen, A., Kousa, A., Rönkkö, T. and Hillamo, R. (2016). Physical and chemical characterization of real-world particle number and mass emissions from city buses in Finland. Environ. Sci. Technol. 50: 294-304.

Pirjola, L., Rönkkö, T., Saukko, E., Parviainen, H., Malinen, A., Alanen, J. and Saveljeff, H. (2017). Exhaust emissions of non-road mobile machine: Real-world and laboratory studies with diesel and HVO fuels. Fuel 202: 154-164.

Pitchford, M., Malm, W., Schichtel, B., Kumar, N., Lowenthal, D. and Hand, J. (2007). Revised algorithm for estimating light extinction from IMPROVE particle speciation data. J. Air Waste Manage. Assoc. 57: 13261336.

Ravindra, K., Sokhi, R. and Van Grieken, R. (2008). Atmospheric polycyclic aromatic hydrocarbons: Source attribution, emission factors and regulation. Atmos. Environ. 42: 2895-2921.

Schauer, J.J., Kleeman, M.J., Cass, G.R. and Simoneit, B.R.T. (1999). Measurement of emissions from air pollution sources. 2. $\mathrm{C}_{1}$ through $\mathrm{C}_{30}$ organic compounds from medium duty diesel trucks. Environ. Sci. Technol. 33: $1578-1587$.

Seinfeld, J.H. and Pandis, S.N. (2006). Atmospheric chemistry and physics: From air pollution to climate 
change, 2nd Edition. Wiley, New York, pp. 265-266.

Shah, S.D., Ogunyoku, T.A., Miller, J.W. and Cocker, D.R. (2005). On-road emission rates of PAH and $n$-alkane compounds from heavy-duty diesel vehicles. Environ. Sci. Technol. 39: 5276-5284.

Shrivastava, M.K., Subramanian, R., Rogge, W.F. and Robinson, A.L. (2007). Sources of organic aerosol: Positive matrix factorization of molecular marker data and comparison of results from different source apportionment models. Atmos. Environ. 41: 9353-9369.

Sippula, O., Stengel, B., Sklorz, M., Streibel, T., Rabe, R., Orasche, J., Lintelmann, J., Michalke, B., Abbaszade, G., Radischat, C., Gröger, T., Schnelle-Kreis, J., Harndorf, H. and Zimmermann, R. (2014). Particle emissions from a marine engine: chemical composition and aromatic emission profiles under various operating conditions. Environ. Sci. Technol. 48: 11721-11729.

Smith, K.R., Jerrett, M., Anderson, H.R., Burnett, R.T., Stone, V., Derwent, R., Atkinson, R.W., Cohen, A., Shonkoff, S.B., Krewski, D., Pope III, C.A., Thun, M.J. and Thurston, G. (2009). Public health benefits of strategies to reduce greenhouse-gas emissions: Health implications of short-lived greenhouse pollutants. Lancet 374: 2091-2103.

Turpin, B.J. and Lim, H.J. (2001). Species contributions to $\mathrm{PM}_{2.5}$ mass concentrations: Revisiting common assumptions for estimating organic mass. Aerosol Sci. Technol. 35: 602-610.

Wang, F., Li, Z., Zhang, K., Di, B. and Hu, B. (2016). An overview of nonroad equipment emissions in China. Atmos. Environ. 132: 283-289.

Wang, Y.F., Huang, K.L., Li, C.T., Mi, H.H., Luo, J.H. and Tsai, P.J. (2003). Emissions of fuel metals content from a diesel vehicle engine. Atmos. Environ. 37: 4637-
4643.

Wu, B.B., Shen, X.B., Cao, X.Y., Yao, Z.L. and Wu, Y.N. (2016). Characterization of the chemical composition of $\mathrm{PM}_{2.5}$ emitted from on-road China III and China IV diesel trucks in Beijing, China. Sci. Total Environ. 551552: 579-589.

Yunker, M.B., Macdonald, R.W., Vingarzan, R., Mitchell, R.H., Goyettee, D. and Sylvestre, S. (2002). PAHs in the Fraser River basin: a critical appraisal of PAH ratios as indicators of PAH source and composition. Org. Geochem. 33: 489-515.

Zavala, M., Huertas, J.I., Prato, D., Jazcilevich, A., Aguilar, A., Balam, M., Misra, C. and Molina, L.T. (2017). Real-world emissions of in-use off-road vehicles in Mexico. J. Air Waste Manage. Assoc. 67: 958-972.

Zhang, Y.Z., Yao, Z.L., Shen, X.B., Liu, H. and He, K.B. (2015). Chemical characterization of $\mathrm{PM}_{2.5}$ emitted from on-road heavy-duty diesel trucks in China. Atmos. Environ. 122: 885-891.

Zheng, X. (2016). Emission characteristics of black carbon and polycyclic aromatic hydrocarbon from heavy duty diesel vehicles based on PEMS method. Doctoral dissertation. Tsinghua University. Beijing, China

Zheng, X., Wu, Y., Zhang, S.J., Hu, J.N., Zhang, K.M., Li, Z.H., He, L.Q. and Hao, J.M. (2017). Characterizing particulate polycyclic aromatic hydrocarbon emissions from diesel vehicles using a portable emissions measurement system. Sci. Rep. 7: 10058.

Received for review, September 1, 2018

Revised, March 11, 2019 Accepted, May 20, 2019 